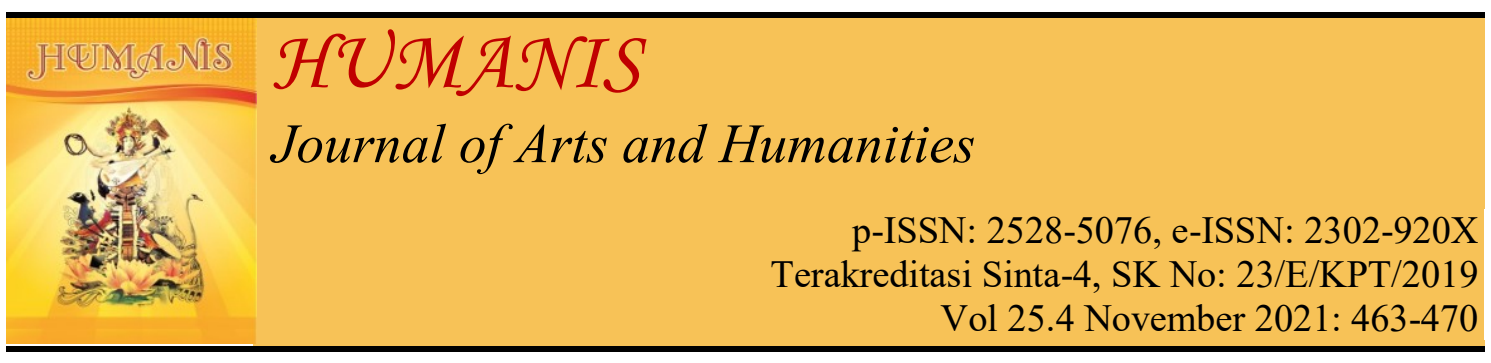

\title{
Compound Nouns Found in The Jakarta Post Website
}

\section{Erisa Octavianti, Ni Luh Sutjiati Beratha, Ni Wayan Sukarini}

Udayana University, Denpasar, Bali, Indonesia

Correspondence email: erisaocta@gmail.com, sutjiati59@gmail.com, wayan_sukarini@unud.ac.id

\begin{tabular}{|c|c|}
\hline Article Info & Abstract \\
\hline $\begin{array}{l}\text { Submitted: } 7^{\text {th }} \text { May } 2021 \\
\text { Revised: } 31^{\text {st }} \text { May } 2021 \\
\text { Accepted: } 3^{\text {rd }} \text { June } 2021\end{array}$ & $\begin{array}{l}\text { This study is aimed to identify the types of compound nouns } \\
\text { and analyze the meanings of compound nouns conveyed on } \\
\text { The Jakarta Post website. Two theories applied in this study, } \\
\text { the theory of compound proposed by Katamba and the theory } \\
\text { of meaning proposed by Palmer. Eight articles from The }\end{array}$ \\
\hline $\begin{array}{l}\text { Keywords: } \\
\text { Compound noun, meaning, } \\
\text { article. }\end{array}$ & $\begin{array}{l}\text { Jakarta Post website were chosen as the data source. The } \\
\text { selected articles are related to technology, lifestyle, and } \\
\text { business from December } 2020 \text { until February 2021. } \\
\text { Documentation method and note-taking technique used in }\end{array}$ \\
\hline $\begin{array}{l}\text { Corresponding Author: } \\
\text { Erisa Octavianti } \\
\text { Email: erisaocta@gmail.com }\end{array}$ & $\begin{array}{l}\text { collecting the data. The collected data was analyzed by using a } \\
\text { descriptive qualitative method and triangulation technique. } \\
\text { Meanwhile, in presenting the data analysis, this study used } \\
\text { formal and informal methods. The result shows that all types of }\end{array}$ \\
\hline $\begin{array}{l}\text { DOI: } \\
\text { https://doi.org/10.24843/JH.202 } \\
\text { 1.v25.i04.p06 }\end{array}$ & $\begin{array}{l}\text { compound nouns based on the theory applied are found in the } \\
\text { data source. The types are: noun }+ \text { noun, adjective }+ \text { noun, } \\
\text { and preposition }+ \text { noun. In terms of meaning, there are } \\
\text { transparent and opaque meanings. }\end{array}$ \\
\hline
\end{tabular}

\section{INTRODUCTION}

Morphology is the process that refers to the part of the grammar that is concerned with words and word formation stated by O'Grady and Guzman (1996). This process includes the ways new words are coined in the world's languages (Lieber, 2009). Morphology deals with words, their internal structure, and how they formed (Aronoff and Fudeman, 2011). Nowadays people are readily accepting new things, including written or spoken word formation, because of globalization's influence.

Globalization is the growth or development of the world's economics, technologies, cultures, and even population. The field that is experiencing the fastest globalization is technology.
One of the benefits that affect people nowadays can be seen in information and communication technology. People can access information everywhere they want to through various media, such as; television, radio, newspapers, etc. The news that is not printed is called digital news.

One of the digital news websites is The Jakarta Post. The articles on this website contain new words related to the word-formation process, especially compounding. Compounding is the process of putting words together to build a new one that does not denote two things, but one and that is pronounced as one unit (Wisniewski, 2007). The common types of compounds are 
compound nouns, compound adjectives, and compound verbs.

A compound noun is made up of at least two constituents, which different word classes of constituents can form. Katamba (1993) stated that compound nouns might appear in different types. The compound nouns consist of any word classes followed by a noun. Furthermore, a compound noun is the way toward combining words into solitary word and makes them mean. However, the meaning of the elements might be lost and framed another meaning. The compound processes do not just carry on framing words yet additionally examine the implications. The meaning of the compound noun sometimes can and cannot be identified from its constituents (Palmer, 1981).

Among the other types of compound words, compound nouns are interesting since they are the most frequent types of compound used either in utterance or written. The Jakarta Post website is chosen as the data source because the digital news provides many compound nouns.

In light of the above explanation, it is energizing and valuable to talk about compound noun. This study focused on identifying and analyzing the types of compound nouns and their meanings found on The Jakarta Post website.

\section{METHOD AND THEORY}

The data of this study is digital data and was taken from The Jakarta Post website. The Jakarta Post can be accessed on its website www.thejakartapost.com through mobile phone or computer. In this study, the news text related to technology, lifestyle, and business from December 2020 until February 2021 was used as the data source. The reason for choosing the articles from The Jakarta Post website is that it contains compound words, especially compound nouns that relevant to the topic of this study.

Documentation method was used to collect the data source from The Jakarta Post website. Next, the technique of collecting data was done by taking notes and classifying them into compound nouns. The process of collecting data was done by specific techniques. First, selecting the articles from The Jakarta Post website, then printing them out. Second, reading the articles carefully to find out the compound words which belong to compound noun. Third, making the highlights of the articles, which were considered as compound nouns. Last, taking notes of the articles that have been marked.

The collected data was analyzed using the descriptive qualitative method. This study also used the triangulation technique, which means the data were checked a couple of times to see the validity of the data (Creswell, 2017). The cross-checking data was carried out based on the theories applied. First, the data was classified into some types of compound nouns using the theory of compound proposed by Katamba (1993). Furthermore, the compound nouns that had been classified were analyzed based on their meanings using the theory from Palmer (1981).

The data analysis was presented using formal and informal methods. In presenting the data, a few stages are taken. To start with, the data analysis was calssified into types of compound nouns. Second, each of the data was presented in a tree diagram to show its components. Last, an explanation of the type and meaning was elaborated below the tree diagram in a paragraph.

Several articles are related to the topic of this study. An article related to this topic entitled English Compound Nouns in Short Story "The Star-Child" by Oscar Wilde written by Pratiwi 
(2018). This article used the theory of compound words by Katamba (1993), which was partitioned into three kinds dependent on the semantic head. There are exocentric, endocentric, and copulative. Her article also used the theory of meaning proposed by Palmer (1981) to explain the meanings of compound nouns.

The second article entitled Compound Words Found in SeventySeven Thousand Service-Trees (Sri Chinmoy) written by Damayanti (2020). Her article aimed to describe the types and the construction of compound words. Two theories were applied in her article, theory by Booij (2007) and McCarthy (2002). The result showed that compound noun is the most successive type that occurred in the data source and based on its form, there was a solid and hyphenated form of compound words.

Another article was published in an international journal entitled IndonesianEnglish Compound Word Equivalence written by Hikmaharyanti (2020). This article aimed to analyze IndonesianEnglish compound words translation equivalence since both had different classifications and characteristics to be investigated. She used the novels of Lelaki Harimau and the English version of Man Tiger as the data source.

This study applied two theories in analyzing the data. First, the theory of compound nouns by Katamba (1993). A compound noun can be defined as a type of compound word with a noun as its head, whether the head appears at the left or the right of the compound. Katamba (1993:305) stated that compound noun consists of three sub principles;

1. A noun followed by another noun (Noun + Noun)

2. An adjective followed by a noun (Adjective + Noun)

3. A preposition followed by a noun (Preposition + Noun).
In order to give an understanding of the meanings of compound nouns, this study also applied the theory of meaning proposed by Palmer (1981). Palmer, in his book, divided meaning into two types; transparent and opaque meaning. Transparent meaning is the meaning of the words that can be determined from the meaning of each part. Meanwhile, opaque meaning is not predictable to be determined from the meaning of its constituents.

\section{RESULT AND DISCUSSION}

This part presents results and discussions of the data from The Jakarta Post website which has been analyzed based on the types of compound nouns by Katamba (1993) and it is additionally trailed by the examinations of meanings contained in compound nouns including transparent and opaque meaning based on the theory of meaning by Palmer (1981).

\section{Compound Noun + Noun}

Compound noun is a type of compound word that consists of a noun followed by another noun (Katamba, 1993). In this type of compound, the head may appear at the left or the right of a compound. As stated by Booij (2002), compounding is the most frequently used way of making a new lexeme. Example 1

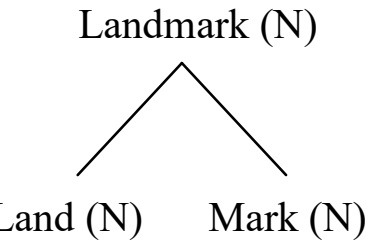

Morphologically, the compound word landmark is formed by combining two independent words; land $(\mathrm{N})$ and mark $(\mathrm{N})$. Both of the words framed another word that has a place to a compound noun with the 'Noun + Noun' pattern. As indicated by Plag (2003), noun + noun pattern is the most widely recognized kind of compound. The word 
mark functioned as the head, while the word land as a modifier. It means that the head appears on the right. The compound noun landmark is a closed compound because another follows the first component without space.

The words land and mark have distinct meanings. The word land can be defined as a solid part of the earth's surface that does not contain water. Meanwhile, the word mark has a lexical meaning as a spot or line with a different color in some ways. After these words combine and form a new compound noun, it has one meaning which cannot be identified from its components. Since the meaning of the compound noun cannot be resolved from its parts, it includes to an opaque meaning (Palmer, 1981). The compound noun landmark can be defines as 'an object or building that can easily be seen from distances.' Example 2

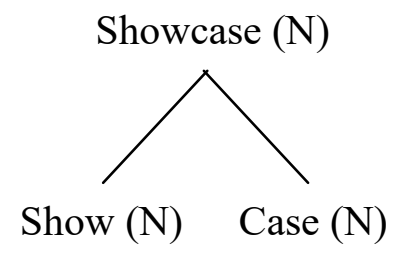

The compound noun showcase consists of two parts; show $(\mathrm{N})$ and case $(\mathrm{N})$. The two words are joined and framed another word that belongs to compound noun with 'Noun + Noun' pattern. As stated by Katamba (1993), the compound noun has a head and usually appears on the right. In the compound noun showcase, the word case functioned as the head and the word show as a modifier. It shows that the head appears at the right. The compound noun showcase can be classified as a closed compound since the words are melded together, forming a single new word.

Semantically, the words show and case have distinct meanings. The word show means a performance whose purpose is to entertain the audience.
Whereas the word case can be determined as a box to place something. After these two words are combined and framed another word with one importance. Since the meaning can be distinguished from its constituents, it classifies to transparent meaning. The compound noun showcase can be defined as 'a box made of glass to display valuable objects.'

Example 3

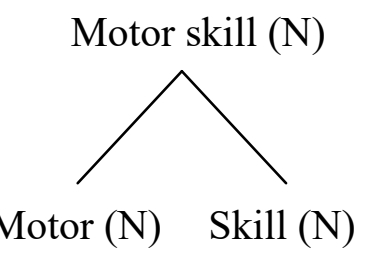

The compound noun motor skill consists of two words; motor $(\mathrm{N})$ and skill $(\mathrm{N})$. Combining these words framed another word that includes in a compound noun with 'Noun + Noun' pattern (Katamba, 1993). It has the word skill as the head, while the word motor as a modifier. The compound noun motor skill can be sorted as an open compound by reason of it consists of two words forming a single new term separated by a space.

The words motor and skill have different lexical meanings. The word motor can be determined as a machine that changes electricity or fuel into motion and makes machines work. Meanwhile, the word skill means an ability to do an action with a good result. Furthermore, these words are grouped and formed compound noun motor skill, meaning 'an ability involves precise movement to perform a specific act.' From the meaning, the compound noun motor skill has a transparent meaning because the meaning can be identified from its elements.

\section{Compound Adjective + Noun}

The second type of compound noun consists of an adjective followed by a 
noun. This type of compound has a noun as the head.

Example 4

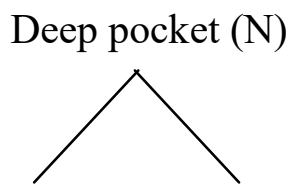

Deep (Adj) Pocket (N)

Scalise (2010) stated that compound word is the combination of lexemes into larger words. In this case, deep pocket is formed by combining two parts; deep (Adj) and pocket $(\mathrm{N})$, and formed a compound noun with 'Adjective + Noun' pattern. In light of its form, the compound noun deep pocket can be sorted as an open compound since there is a space between the first and the followed components. It has a noun as the head and appears at the right, while the adjective functioned as a modifier.

The words deep and pocket have a distinct meaning. The word deep means a position far down from the top or surface. Whereas the word pocket can be determined as a tiny pouch sewn on clothes used to put small articles. Furthermore, these words are grouped and formed compound noun with one meaning where it cannot be identified from its constituents (Palmer, 1981). The compound noun deep pocket means 'an organization or company with extensive or substantial financial resources' and belongs to opaque meaning.

Example 5

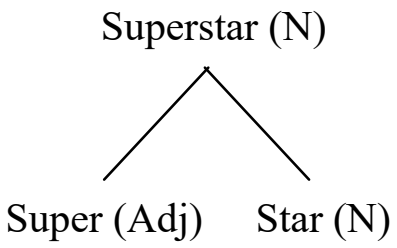

Based on the tree diagram above, the compound noun superstar is formed by combining two words; super (Adj) and $\operatorname{star}(\mathrm{N})$. Both words have different word classes. It framed another word that classifies to a compound noun with
'Adjective + Noun' pattern. Long established and lexicalized compounds tend to be written as one word (Szymanek, 1989). The compound noun superstar sorted as a closed compound since the words are connected without space. The word star functioned as the head, while the word super as a modifier.

Semantically, both words super and star have different lexical meanings. The word super means outstanding or excellent, while the word star can be defined as a giant ball of burning gas seen as a small light in the night sky. Furthermore, these words joined and formed compound noun superstar which has a different meaning from its elements. Some compound nouns cannot be predicted from the meaning of their parts (Indrawati, 2013). Since the meaning cannot be identified from its elements, it includes in opaque meaning. The compound noun superstar can be determined as 'someone is successful, excellent, and widely known in their field.'

Example 6

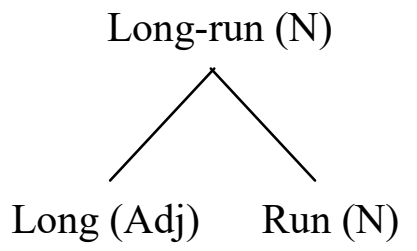

From the tree diagram above, the compound noun long-run is the combination of two words; long (Adj) and $\operatorname{run}(\mathrm{N})$. The two words framed another word that classifies to a compound noun with 'Adjective + Noun' pattern. English has a productive rule of forming compound nouns, consisting of an adjective followed by a noun, as appears in this analysis (Bennett, 2002). The word run functioned as the head and the word long as a modifier. In view of its form, the compound noun long-run sorted as a hyphenated compound since it 
has a hyphen (-) used to join parts of the word.

Lyons (1977) stated that meaning is a word of the ordinary, everyday vocabulary of English. In terms of meaning, the words long and run have different lexical meanings. The word long can be determined as a significant amount of time. In contrast, the word run means a continuous period of things. Furthermore, these words are grouped and formed compound noun long-run, meaning 'an extended period.' Since the meaning of the compound noun long-run can be identified from its constituents, it classifies to transparent meaning.

\section{Compound Preposition + Noun}

The last type of compound nouns based on the theory proposed by Katamba (1993) is a compound noun with 'Preposition + Noun' pattern. Example 7

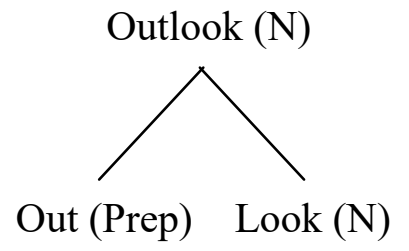

A compound is a word that contains two or more other words (Leech, 2006). The compound noun outlook contains two independent words, namely out (Prep) and look (N). Later on, those words shaped another compound word that falls under to the compound noun with 'Preposition + Noun' pattern. English compound words are mostly Right-headed (Altakhaineh, 2019). In the compound noun outlook, the word look functioned as the head, while the word out as a modifier. In view of its form, it can be classified as a closed compound since the first word is followed by another without space.

From the meaning, each of the components has a different meaning. The word out can be determined as away from the inside of a place or position.
Meanwhile, the word look can be defined as the physical appearance of someone or something in particular. After these words are grouped and formed a compound noun outlook, its meaning is 'an attitude of someone towards life.' The meaning is easy to be determined from its elements (Palmer, 1981). Therefore, it belongs to transparent meaning.

Example 8

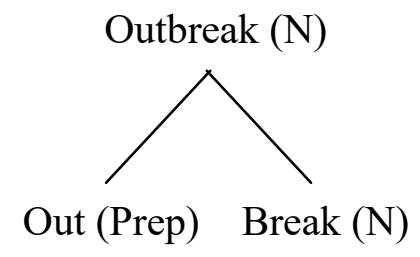

Compounding is the process by which a compound lexeme is derived from two or simpler lexeme (Matthews, 1996). From the tree diagram above, the compound noun outbreak consists of two lexemes, out (Prep) and break (N). Both words formed a new compound noun with the 'Preposition + Noun' pattern. The head appears at the right, and the left constituent functioned as a modifier. Cited from Cahyanti (2016), compounds may consist of two or more lexeme stems that are aligned in a single word form. It can be categorized as a closed compound since the compound noun outbreak is melded together, forming a single word.

Semantically, both words have different lexical meanings. The word out can be determined as away from the inside of a place or position. Meanwhile, the word break means a short period of rest in the middle of activities. Furthermore, these words formed a compound noun with one meaning that cannot be defined from its constituents. Since the meaning is different from its constituents, it falls under to an opaque meaning. The compound noun outbreak can be defined as 'a sudden start of 
something terrible, especially disease or catastrophe.'

\section{CONCLUSIONS}

Based on the previous analysis, this study focused on identifying the types of compound nouns using the theory by Katamba (1993) and analyzing the meaning of compound nouns using the theory by Palmer (1981). Some points can be drawn as conclusions.

All the three types of compound nouns based on the theory proposed by Katamba (1993) are found in eight articles on The Jakarta Post website. They are a noun followed by another noun (Noun + Noun), an adjective followed by a noun (Adjective + Noun), and a preposition followed by a noun (Preposition + Noun).

Moreover, there are two meanings of compound nouns found in the data source. Transparent meaning is the meaning of the words that can be determined from the meaning of each part. Meanwhile, opaque meaning is not predictable to be determined from the meaning of its constituents.

\section{REFERENCES}

Altakhaineh, A. R. M. (2019). A Crosslinguistic Perspective on the Righthand Head Rule: the Rule and the Exceptions. Linguistics Vanguard, 5(1), pp. 1-11.

Aronoff, M., and Fudeman, K. (2011). What is Morphology? 2nd ed. United Kingdom: Wiley Blackwell.

Bennett, P. (2002). English AdjectiveNoun Compounds and Related Constructions. GEMA Online Journal of Language Studies, Volume 2, pp. 1-10.
Booij, G. (2002). The Grammar of Words: An Introduction to Linguistic Morphology. 2nd ed. New York: Oxford University Press Inc.

Cahyanti, R. D., 2016. Compound Word Used in Stephenie Meyer's Twilight. Journal on English as a Foreign Language, 6(1), pp. 59-70.

Creswell, J. W., and Creswell, J. D. (2017). Research Design: Qualitative, Quantitative, and Mixed Methods Approaches. 5th ed. United Kingdom: SAGE Publications, Inc.

Damayanti, L. (2020). Compound Words Found in Seventy-Seven Thousand Service-Trees (Sri Chinmoy). $e$ Journal of Linguistics, Volume 14, pp. 268-275.

Hikmaharyanti, P. D. A. (2020). Indonesian-English Compound Word Equivalence. International Journal of Language and Cultural, II(01), pp. 75-86.

Indrawati, N. L. K. M. (2013). Noun Compound in English. Lingual Journal of Language and Culture, Volume 1.

Katamba, F. (1993). Morphology. London: Macmillan Press Ltd.

Leech, G. (2006). A Glossary of English Grammar. Edinburgh: Edinburgh University Press Ltd.

Lieber, R. (2009). Introducing Morphology. Cambridge: Cambridge University Press.

Lyons, J. (1977). Semantics. Cambridge: Cambridge University Press. 
Matthews, P. H. (1996). Morphology. 2nd ed. Cambridge: Cambridge University Press.

O'Grady, W., and Guzman. (1996). Contemporary Linguistics: An Introduction. United Kingdom: Longman.

Palmer, F. R. (1981). Semantics. Cambridge: Cambridge University Press.

Plag, I. (2003). Word-formation in English. New York: Cambridge University Press.

Pratiwi, M. D. 2018. English Compound Nouns in Short Story "The Star Child" by Oscar Wilde. Jurnal Humanis, 23(1), pp. 148-155.

Scalise, S. (2010). Cross-Disciplinary Issues in Compounding. Amsterdam: John Benyamin Publishing.

Szymanek, B. (1989). Introduction to Morphological Analysis. Warszawa: Pantswowe Wydawinictwo Naukowe.

Wisniewski, K. (2007). Word Formation Processes: How New Words Develop in the English Language. New York: Blackwell. 